\section{二次情報の活用 $(1)$}

\section{\二次情報を利用する前に}

われわれのまわりにある文献情報は，近年ものすごい 勢いで増加しつつある.したがって，オリジナルを自分 で一々眼を通していれば十分というような分野は段々と めずらしいるのとなってきた。それでも，特定の分野に おいてはこの種の一次情報のみが情報源であるために， いやが応でも原文献を見ておく必要がある.

このような場合には, 新着雑誌を端からパラパラとめ くって丹念に目を通すことになるが，熟練した先生方に なれば，流れるように目を通し，要るところだけをメモ したりするよらになる。この通読（流し読み）のことを ブラウジングという． 天下の形勢を把握したり，あるい は何かきわめてユニークなことを拾い出すには，いまで もこのブラウジングは不可欠である.

しかしながら，そらはいっても全部の新着雑誌に目を 通すのは大変である.さきにも述べた Chemical Abstracts では, 1981 年には 50 万件弱のものが採録されて いる. 1 年は 365 日，分に直して 526,000 分弱であるか ら，もし全部を一人で見るとしたら，寝食を度外視して も 1 分間に 1 件の論文を見なくてはならない。

そこで二次情報誌の出番となるわけであるが，これと ても，このような大規模なものとなっては索引もつくり にくいし，かつ時間を要することになる。もし練達の文 献処理のできる人間（米国では Literature Chemist と 呼ばれ，かなり高給をもって待遇されているらしい）が いるならば,この中から必要なものだけを上手にセレク トして提供してもらえよう。

しかしながら，わが国においては，このような特殊技 能をもっている方々はきわめて少ない，会社などには資 料室というセクションのあるところが多いけれどむ， 爪 聞するところでは，とかく空際族の配転用のポジション としてしか利用されていない所が多いとか：大体, 資料 を取り扱ら人間はやはり情報畑のエキスパートであるへ
きなのであるのに，これではその用をなしえない，

一方これと同様な機能を果たしてくれるはずのもの にライブラリアン (図書司) がある. 欧米の図書館のラ イブラリアンは，この種の参考業務に興味をもたれる方 が多いようであり，その活動もかなり積極的である。し かしわが国では，いくら橎訳の本に,「わからないことは 図書館の人に訊视ることをすすめる」と書いてあったと しても，まずは実行不可能である．彼ら（彼女ら）はあ くまで本はしまっておくもので, 閲覧は第二番目（参考 業務などできるほどの能力はもともとない)，UDC（国 際十進分類）をつけることが至上命令, 義務としか心得 ていないのが大部分である。もちろん中にはきわめてす ぐれたタレントの持主もいるのだ，このような方々に 対しては図書館のほうの扱いがツメタイらしい.

そらいらことになれば, われわれは何とかして, 自分 で上手にものを探す方法を模索せねばならない。

冊子体になっているものが，以前の二次情報のほとん どであったが，近年は磁気テープに載ったコンピュータ 可読の形（データベース）のものも次第に普及しつつあ る.このシリーズでは両方に関して述べることにする が, 新しいデータベースについてはやや詳しく記す。

\section{\再現率と精度}

もの探しを他人に頼んだ場合を考えてみる.「カクカク シカジカのものが，あの紙の山の中にあるはずだから， お前全部探してもってこい」といらょらな命令を出すだ ろう.この時, 頼まれたほうが優秀な人であれば, 洩れ なく全部を探し出し，要らぬもの弾き出してくる．乙 かし，多少とも足りない人物であったら，探し出してき たものの中に，必要なものはちょっとだけで，大部分は 不要なものとなるし，しかも当然あるはずのものがぬけ ているということになる。

このようなケースの指標となるものとして，情報検索 に拈いては, 再現率 (relevance) と精度 (precision) と いらものを用いる．この定義は下のょうである.

再現率 $R=\frac{\text { 検索結果中の必要なものの数 }}{\text { 原集合中の必要なものの数 }} \times 100(\%)$

精 度 $P=\frac{\text { 検索結果中の必要なものの数 }}{\text { 原集合から検索したものの総数 }} \times 100(\%)$

いま，原集合，たとえば Chemical Abstracts 半年 分の中で, ジベレリンに関する文献がちょうど 200 件あ 
ったとする(しかし、これはあとからわかることであ る)、この検索を文献を文献検索実習として，阿川，豊 野, 手苗, 堂島の各君に依頼した結果が次のようになっ たとしょうか。

\begin{tabular}{|c|c|c|c|c|}
\hline 検索者 & 結果 & $\begin{array}{l}\text { 文献数 } \\
\text { (件) }\end{array}$ & $\begin{array}{l}\text { そのうち必要 } \\
\text { なもの(件) }\end{array}$ & $R$ \\
\hline 阿 川 & (A) & 180 & 180 & 90 \\
\hline 野 & (B) & 200 & 200 & 100 \\
\hline 田 & (C) & 250 & 200 & 100 \\
\hline 島 & (D) & 200 & 100 & 50 \\
\hline
\end{tabular}

この中で，いつも結果が理想的であることが前もって わかっているならば，（B)のような結果が望ましいのは いうまでもないしかし，はじめから探すべき対象の数 がはっきりわかっているのは比較的少数例である。そう すると，われわれは常にある程度の拾い落としの危険性 があるものと覚悟しておいた活らがよい，

すると，安全のためには（C)のような結果であるほう が望ましい，つまり，余分なるの（ノイズ）がかなり入 っているが，求めるものは少なくとも全部拾い出してあ るといらことになる。人間 (学生) 相手なら,「コレジャ ダメ! ヤリナオシ!!」ということも可能である.しか し、 コンピニータによる検索の場合も，まったく同しこ とがおこるし，この場合は相当の扣金（費用）を用意し ておくことになる。

(A)のような結果を出すと，大抵の人は喜ぶものであ る.つまり $P=100 \%$ だからである。しかし、これには 10\%のミス（拾い落とし）があることは，(B)，(C)と 比べてはじめてわかる．初心者の検索は往々にしてこの (A)のように，あるいは(D)のように（件数だけ合わせ たもの)なりやすい.

われわれが検索を依頼する場合，理想的な相手は（C) のような結果をつくる千田君のような人（あるいは検索 プログラム)である.〈れぐれも阿川君や豊野君のよう な，一見キレイな結果を信用してはならない。およその 目安として, $R=100 \%$ (必ず)，P=60 80\% がいいと ころである. $P=100 \%$ とい5結果を初めての人間が出 したらまずは見落としがあるものと考えるほうがよい，

\section{『票芸化学に関係するデータベース，二次情報（1）}

農芸化学のカヴァーする範囲はきわめて広いから，化 学, 生物, 地質などの基礎的な部門から, 食品, 獣医学,
さては医学や経済統計なども関係のない部門とはいえな い.ここではまずはじめに, 農学, 生物学関係のデータ ベース類について解説を加えておくことにしよう．利用 のためには，表 $1 ， 2$ を参考とされたい

農学関係の最大のデータベースは, 英国の農業省 (Commonwealth Agricultural Bureaux) から出されて いる CAB である.これに次いでは米国農学図書館から の AGRICOLA, FAO からの AGRIS などがある.さ らに米国内の研究機関の研究テーマを網羅したクリアリ ングサーヴィスとしての CRIS むあげて打く要がある.

生物学をカヴァーする最大のデータベニスは BIOSIS である.この他, 生物化学を重点的に集めた CBAC が あるがこれは Chemical Abstracts の部分集合であ るから今回は特に触れないこととしよう。

水産, 海洋学畑のデータベースとじては, MRIS (Maritime Research Information Service) p ASFA (Aquatic Science and Fisheries Abstracts) がある.

利用者が限定されている（会員制をとっている）もの で, 多少一般性㳄欠ける点はあるが, 獣医学データベー スの VETDOC，あるいは殺虫剤，農薬専門の PESTDOC などもくく利用されている．この $2 つ$ つ, 英国 Derment 社が拈手のものの特許文献をデータベース化 したものである.他に, FARMDOC, AGDOC (薬学, 農学をカヴァー) などがあり, 化学関連特許文献の中の 特殊部門となっている.これについては回をあらためて 述べることにしょう。

農芸化学と密接な関係にある部門の一つに, 環境問題 がある.これに関しては，文献情報集の EPB (Environmental Periodicals Bibliography) の伍, ESI (Environmental Science Index), Pollution Abstracts など がある。

食品部門も関連の深い分野であるが，こちらは工学的 色彩がどうしても強くなる、したがって，工業界のほう に主力をおいてつくられたものとなるが，FSTA (Food Science and Technology Abstracts) と FOOD ADLIBRA があげられる. 後者はマーケッティングや経営 ニュースなどすふくまれる. Chemical Abstracts の部 分集合として, CBAC と同じように Ecology and Environment, Food and Agricultural Chemistry があるが, CASearch に拡充され一本化された現在では特に記すほ ぞのこともないだろう。 
表 1 農学, 生物学, 懪境関連のデータベースー監

\begin{tabular}{ll}
\hline \multicolumn{1}{c}{ 名 $\quad$ 称 } & \multicolumn{1}{c}{ サーヴィ ス機関 } \\
\hline AGRICOLA & DIALOG, ORBIT, BRS \\
ASFA & DIALOG \\
BIOSIS PREVIEWS & DIALOG, ORBIT, BRS, JOIS, 筑波大, 広島大 \\
CAB & DIALOG, ORBIT, JOIS, 筑波大 \\
CRIS & DIALOG \\
ENVIROLINE & DIALOG, ORBIT, 筑波大 \\
DPB & DIALOG \\
FOOD ADLIBRA & DIALOG \\
FSTA & DIALOG, ORBIT \\
OCEANIC ABSTRACTS & DIALOG, ORBIT \\
POLLUTION ABSTRACTS & DIALOG, ORBIT, BRS, 筑波大 \\
\hline
\end{tabular}

あるすべての文献に抄録がつけられ ているわけではないが，重要なもの にはすべて抄録が付されている。

\section{- AGRICOLA}

これは米国農業図書館 (National Agricultural Library) の所蔵する 畫籍，文献を網羅した，目録，索引 のデータベースであり，世界中の逐 次刊行物, 書籍（単行本など）で,

農学および関連分野を洩机なく収録
これらのデータベースは, 丸善の MASIS, 紀伊国屋 畫店の ASK (ともに DIALOG のサーヴィスを担って (るる) や日本 SDC(ORBIT) などを利用して検索が可能 である．国内では筑波大学や広島大学に BIOSIS など関 連のあるもの 2,3 がオンライン化されている。まとめ て表1に示しておくとしょう。

\section{『各データベースの解説}

\section{- CAB ABSTRACTS}

毎年約 13 万件の情報をふくむ英国農業局 $\mathrm{CAB}$ からの 包括性の大きいファイルである. CAB からは 26 種類の 抄録誌（表 2）が刊行されているが，この中にはすでに 目にされたものも少なくないだろう．このすべてを包含 した農学，生物学情報の大集合である.データベースに

\section{表 2 CAB より発行の抄録誌一管*}

Animal Breeding Abstracts

Apicultural Abstracts

Dairy Science Abstracts

Field Crop Abstracts

Forest Products Abstracts

Forestry Abstracts

Helminthological Abstracts $(A \& B)$

Herbage Abstrates

Horticultural Abstracts

Index Veterinarius

Nutrition Abstracts and Reviews $(A \& B)$

Plant Breeding Abstracts

Protozoological Abstracts

Review of Applied Entomology ( $A \& B$ )

Review of Medical and Veterinary Mycology

Review of Plant Pathology

Rural Development Abstracts

Rural Extension, Education and Training Abstracts

Rural Sociology Abstracts

Soils and Fertilizers

Veterinary Bulletin

Weed Abstracts

World Agricultural Economics
することを目的としている．CAB とちがって，冊子体 のものに必ずしも対応しているわけではないが,「一般的 な大図書館に含まれる，すべての主題分野を実質的にカ ヴァーした収録が提供できる」という宣伝文句は掛值の ないものとしてよかろう。

\section{- CRIS}

わが国においては日本科学技術情報センター(JICST) にクリアリングファイルといらものがあり，国内の国 公立研究機関の研究テーマやプロジェクトの現況ををと めてデータベースとしたものである。これの米国農務 省 (USDA) 版ともいえるのがこの CRIS (Current Research Information System) である。米国内に括汸る USDA の研究部門，あるいは州立の農業試験場や林業 学校などで行なわれている農学, 関連科学の現行の研究 を包含したものである. 食品, 栄養, 消費者の安全, 保 健, 環境保護などから, 天然資源, 地域開発, 市場, 都 市などまでの広い範囲がふくまれる、自然科学のみなら ず, 社会学, 経済学や行動科学までも対象となっている.

\section{- BIOSIS (BIOSIS PREVIEWS)}

生物学といらよりむしろ生命科学一切をカヴァーして いる Biological Abstracts と, 同じ発行元からの Bioresearch Index の両方を包括したデータベースがこの BIOSIS PREVIEWS である. 年間に約 30 万件の採録 数は後述 (次号)の Chemical Abstracts に次ぐもので ある. 対象は生物科学の全分野であるが，関連の深いと ころとして化学や医学の情報をもかなり大量にふくんで いる. 計算機での利用に際してよく問題となる用語集と しては, BIOSIS MASTER INDEX があり, 生物コー ド，分類コードなどがまとめられているが，あまり撖密 な統制キーワードシステムは採用されていない。このキ ーワード統制については，次号以下であらためて述べる 


\section{こととしょう.}

\section{- FSTA と FOOD ADLIBRA}

食品科学, 食品工業に関するデータベースとしてはこ の 2 種があげられよう．FSTA は英国にある International Food Information Service の発行で, 食品科学 を中心とし, 関連の農学, 生物学, 家政学, 化学, 生化 学, 物理学などの分野を包括している. 関連する工学的 な面もふくまれる. FOOD ADLIBRA は，どちらかと いうと食品工業のほうに中心があり, 栄養, 毒物学的情 報から，食品加工，販壳までをらくむ食品産業全分野 と，包装の新技術，マーケッティングなどをカヴァーし ている.こちらは米国の K \& M Publication の発行 である.

\section{・その他}

ASFA は Aquatic Science and Fisheries Abstracts をコンピュータ可読のデータベース化したるので, 米国 の NOAA の提供である. 海洋, 陸水の生命科学の注か, 関連した社会的主題を包括していて, 水柍生物, 漁業, 水質污染などに関してのすぐれた情報源である.

Oceanic Abstracts は海洋学主体であり, 海洋生物, 地質学, 地球物理学, 気象学などのアカデミックな部分 から，海運業，船舶，海事法などの社会，行政面までの 情報をふくむ。

環境関連のデータベースとしては, ENVIROLINE，
EPB および Pollution Abstracts があげられよう.

ENVIROLINE は ESI と略称されたこともあるが， 世界中の環境情報を学際的に収録している，地質，生物， 化学などの自然科学面から, 法律, 政治, 工業技術, マ ネージメントなどに至る広い範团をふくむ。

EPBは, The Environmental Periodicals Bibliography の略称であり，一般人間生態学，大気，エネルギー, 陸地資源之水資源, 栄養, 衛生の分野が対象となる. 収 録件数は ENVIROLINE より多いが，刊行物の種類は 逆にやや少なくなっている。

Pollution Abstracts は, 二次情報（データベース） の大手発行元の一つ Data Courier, Inc., からのもので ある. 主対象 (主題分野) は大気污染, 環境基準, 騒 音, 農薬, 放射能, 廃棄物と水質污濁などであり, 環境 污染と污染防止に関する文献データベースである.

この浪か，冊子体，かつ日本語で記されているために よく用いられている日本科学技術情報センターの科学技 術文献速報の環境公害篇も，用い方によってはきわめて 便利である.ただし，この種のものの常として，日本語 に直すまでにかなりの時間を必要とするから，迅速性を 重んじる向きには不適当である.

(つづく)

（飯壊 健*, 山䗁 械**, *群馬大学一般教育,

**電気通信大学共通講座)

評

\section{“味覚の科学”}

\section{佐藤昌康 編}

本書は 1972 年に発行された「味覚, 嗅覚の科学」(朝倉書 店）と同じ編者によるものであるが，執筆者の陣容も変り，そ

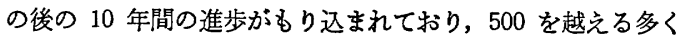
の参考文献の 6 割以上が 1972 年以降のものである.

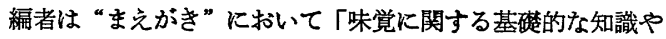
最近の進歩が，専門外の人々に正しく，広く伝えられていると は思学ない. 他方, 心理学, 生理学, 化学の分野からの味覚の 研究は，過去 20 年間にめざましい展開をしている. 本書は, 味覚の諸問題について，研究の現状を紹介するために編まれた るのである」と述べている.

内容は，I. 味覚の神経的基磾，II. 味覚の化学的基礎,
III. 味覚の心理学的基碟, IV. 味覚と健康の 4 部から成り, 味 覚に関するあらゆる面が包括されているが，神経的基礎の部に 全体の約半分がさかれている。これは編者がその分野の尃門家 であること，またこの分野からの研究が最も活発におこなわ れ，進んでいることを示するのであろう。

味覚の受容器, 情報の云達などについて, 種々の動物を用い ての電気生理学的研究成果, 味覚不全, 甘, 苦味と化学構造の 関係など味覚に関する最新の科学知識がわかりやすく記述され ており, 興味深い。また，昆虫の甘味受容機構，魚類の味覚と 摂慨行動などがとりあげられており，生化学，食品化学のみな らず昆虫, 水産, 畜産関倸の研究者にも参考々なる書であろう. 殊に，味営と密接な関係にある嗅覚，匂いの科学の研究者にと っては，有益な示唆の与えられる害である. (山西 貞) (A 5 判, 282 頁, 5,8000 円 $)$ 